\title{
Viscosities of Iron Blast Furnace Slags
}

\author{
Mao CHEN, ${ }^{1)}$ Dianwei ZHANG, ${ }^{2)}$ Mingyin $\mathrm{KOU}^{1,3)}$ and Baojun $\mathrm{ZHAO}^{1) *}$ \\ 1) School of Chemical Engineering, The University of Queensland, Brisbane, Australia. \\ 2) Shougang Research Institute of Technology, 69 Yangzhuang Street, Beijing, China. \\ 3) School of Metallurgical and Ecological Engineering, University of Science and Technology Beijing, Beijing, China.
}

(Received on January 13, 2014; accepted on March 31, 2014)

\begin{abstract}
The viscosities of the industrial and synthetic iron blast furnace slags have been measured using a custom designed rotating bob apparatus. This advanced apparatus enables control of the gas atmosphere and rapid quenching of the samples on completion of the viscosity measurements. The experiments were carried out using Mo spindle and crucible under ultra-high purity Ar flow. The microstructures and phase compositions of the quenched slag samples were determined by Electron Probe X-ray Microanalysis (EPMA) after the viscosity measurements.

It was found that the viscosities of the industrial slags are lower than those of the corresponding synthetic slags made from pure $\mathrm{Al}_{2} \mathrm{O}_{3}, \mathrm{CaO}, \mathrm{MgO}$ and $\mathrm{SiO}_{2}$. The difference in viscosities between industrial slags and synthetic slags will provide useful indications when applying the results of the synthetic slags to the real iron blast furnace slags. The activation energy of both industrial and synthetic slags is $174 \mathrm{~kJ} / \mathrm{mol}$ and increases with decreasing $\mathrm{MgO}$ concentration. Replacement of $\left(\mathrm{CaO}+\mathrm{SiO}_{2}\right)$ or $\mathrm{CaO}$ by $\mathrm{MgO}$ can decrease the slag viscosity. The viscosity of iron blast furnace slag at $1500^{\circ} \mathrm{C}$ can be estimated by $\mathrm{V}=$ $0.005+0.0262\left[\mathrm{SiO}_{2}\right]+0.0184\left[\mathrm{Al}_{2} \mathrm{O}_{3}\right]-0.0172[\mathrm{CaO}]-0.0244[\mathrm{MgO}]$ which is derived from the present and previous data.
\end{abstract}

KEY WORDS: ironmaking; blast furnace slags; viscosity; $\mathrm{Al}_{2} \mathrm{O}_{3}-\mathrm{CaO}-\mathrm{MgO}-\mathrm{SiO}_{2}$.

\section{Introduction}

The principal components of current iron blast furnace (BF) slags are described by the system $\mathrm{Al}_{2} \mathrm{O}_{3}-\mathrm{CaO}-\mathrm{MgO}-$ $\mathrm{SiO}_{2}{ }^{1,2)}$ The targets of the optimum slag compositions are to minimise slag mass and operating temperature whilst satisfying requirements for removal of sulphur and alkali, and slag tapping. ${ }^{2)}$ In modern ironmaking operations, the hot metal and slag temperatures can be controlled within a narrow range to obtain stable operating condition of the blast furnace. More accurate data on the physiochemical properties of the slag, such as viscosity, are required to optimise the operation of the blast furnace.

A large number of data on viscosity of the synthetic $\mathrm{Al}_{2} \mathrm{O}_{3}-\mathrm{CaO}-\mathrm{MgO}-\mathrm{SiO}_{2}$ slags have been reported. ${ }^{3-10)}$ However, significant discrepancies exist for the reported viscosity data due to the difficulties of high temperature viscosity measurement. In addition to the major components $\mathrm{Al}_{2} \mathrm{O}_{3}$, $\mathrm{CaO}, \mathrm{MgO}$ and $\mathrm{SiO}_{2}$, up to $5 \mathrm{wt} \%$ of other components, such as $\mathrm{S}, \mathrm{TiO}_{2}, \mathrm{MnO}$ and $\mathrm{FeO}$ may also be present in the BF slags. ${ }^{11)}$ It is important to understand the difference between the actual slags and the synthetic slags before the viscosity data of the synthetic slags can be applied in blast furnace operations.

High temperature viscosity measurements are expensive and time-consuming. Different viscosity models ${ }^{12-18)}$ have

\footnotetext{
* Corresponding author: E-mail: baojun@uq.edu.au DOI: http://dx.doi.org/10.2355/isijinternational.54.2025
}

been proposed to predict the viscosities of BF slags in wide composition range. As significant discrepancies are present for the reported viscosity data, these viscosity models are yet to be developed to accurately predict the viscosities of BF slags.

The aim of the present study is to compare the viscosities of BF slags from Shougang and corresponding synthetic slags and also evaluate the accuracy of the existing viscosity models. The systematic and accurate viscosity data will be obtained to optimise the existing viscosity databases and improve the reliability of the modified quasi-chemical viscosity model.

\section{Experimental}

A high-temperature viscosity measurement apparatus was constructed and commissioned at The University of Queensland, Australia ${ }^{19,20)}$ (Fig. 1).

A Brookfield digital rotational rheometer (model LVDV III Ultra) controlled by a PC was used in the present study. A Pyrox furnace with lanthanum chromite heating elements (maximum temperature $1650^{\circ} \mathrm{C}$ ) and $90 \mathrm{~mm}$ uniform temperature zone was employed. The ID of the recrystallised alumina reaction tube is $50 \mathrm{~mm}$. The rheometer placed on a movable platform was enclosed in a gas-tight steel chamber. The rheometer rotated co-axially the alumina driving shaft ( $8 \mathrm{~mm}$ OD) with the cylindrical spindle. The crucible was suspended using an alumina tube (38 $\mathrm{mm}$ OD) and held onto the tube with Pt wires and positioned within the hot zone of 


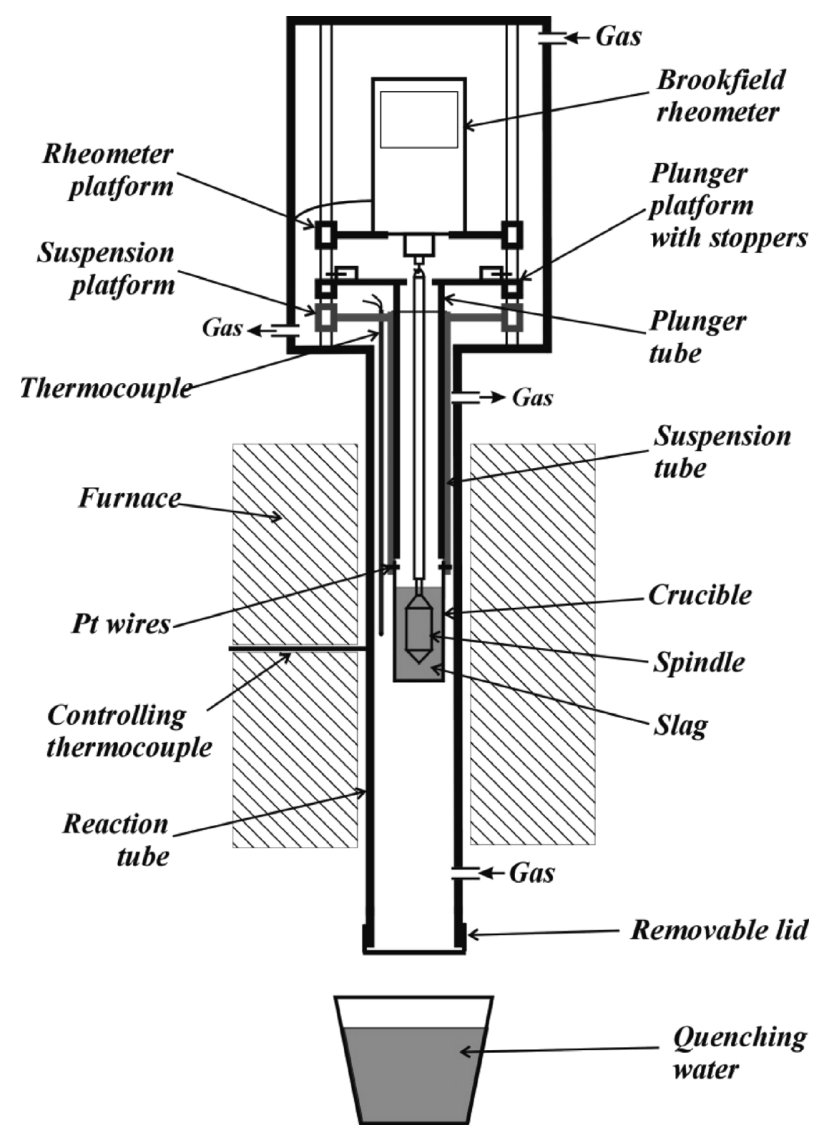

Fig. 1. Schematic of the high temperature viscosity measurement apparatus used in this study.

the Pyrex tube furnace. A Pt-6Rh/Pt-30Rh (B type) thermocouple was bound to the suspension tube platform, the tip of which remained adjacent to the crucible at the level where the spindle rotated. This enabled accurate temperature of the slag to be measured during the viscosity experiments. The measurements of viscosity were usually carried out in the order from high temperature to low temperature in 50 degree interval. At each temperature, the sample was kept for enough time to ensure the chemical equilibration has been achieved which was confirmed by the stable torque readings. The lowest measuring temperature was limited by the liquidus temperature of the slag.

The main feature of the current experimental setup with top suspension was the possibility of quenching the slag sample immediately after the viscosity measurement. This is important to enable the microstructure of the slag and compositions of the phases present in the slag at the temperature to be characterised directly after the viscosity measurement. In this way the uncertainty associated with the changes of the slag composition during the measurements can be minimised. In addition, the presence of crystal and composition change of the liquid due to the precipitation of the crystal can also be identified precisely.

The viscosity of the fluid can be determined by:

$$
\eta=K \frac{M_{s}}{\Omega}
$$

where $\eta$ [Pa.s] is viscosity of a Newtonian fluid, $K$ is the instrument constant, $M_{s}\left[\mathrm{~N} \mathrm{~m}^{-1}\right]$ is the measured torque at a given rotation speed $\Omega\left[\mathrm{m} . \mathrm{s}^{-1}\right]$. The equipment constant $K$,
Table 1. Chemicals used in the present study.

\begin{tabular}{|c|c|c|}
\hline Materials & $\begin{array}{l}\text { Purity } \\
\text { (wt pct) }\end{array}$ & Supplier \\
\hline Silicon oxide $\left(\mathrm{SiO}_{2}\right)$ & 99.9 & $\begin{array}{c}\text { Sigma-Aldrich } \\
\text { (St. Louis, MO, US) }\end{array}$ \\
\hline Calcium Carbonate $\left(\mathrm{CaCO}_{3}\right)$ & 99.95 & $\begin{array}{c}\text { Alfa Aesar } \\
\text { (Ward Hill, Massachusetts, US) }\end{array}$ \\
\hline Aluminium oxide & 99.8 & $\begin{array}{c}\text { Alfa Aesar } \\
\text { (Ward Hill, Massachusetts, US) }\end{array}$ \\
\hline Magnesium oxide & 99.9 & $\begin{array}{c}\text { Sigma-Aldrich } \\
\text { (St. Louis, MO, US) }\end{array}$ \\
\hline Mo spindle/crucible & 99.9 & $\begin{array}{l}\text { Zhuzhou Cemented Carbide Works } \\
\text { (Zhuzhou, China) }\end{array}$ \\
\hline
\end{tabular}

which is a function of the spindle/crucible geometries and the rheometer, can be determined from calibration of the apparatus with fluids of known viscosity. The viscosities of the standard fluids supplied by Brookfield Engineering Ltd are $0.0092,0.0484,0.0968,0.51$ and $0.96 \mathrm{~Pa} . \mathrm{s}$ that cover the range of the slag viscosities to be measured. The same set of Mo crucible and spindle after calibration was used in the high temperature measurement in argon gas atmosphere. Compositional analyses of the quenched samples showed that negligible amount of $\mathrm{MoO}_{3}$ (less than $0.3 \mathrm{wt} \%$ ) was present in the slags. Inspection of the crucible and spindle after the viscosity measurements confirmed that the geometries of the spindle and crucible did not change at high temperatures.

Approximately $35 \mathrm{ml}$ of melted slag was required for each viscosity measurement. Granulated industrial BF slag was used directly for viscosity measurement. Synthetic slag was prepared from pure powders of $\mathrm{SiO}_{2}, \mathrm{CaO}$ (calcined from $\mathrm{CaCO}_{3}$ ), $\mathrm{Al}_{2} \mathrm{O}_{3}$ and $\mathrm{MgO}$ with desired proportions and pelletised. The chemicals used are listed in Table 1. The pelletised sample was melted under ultra-high purity argon $\left(\mathrm{O}_{2}<1 \mathrm{ppm}, \mathrm{H}_{2} \mathrm{O}<2 \mathrm{ppm}\right)$ and the volume of the melt was measured so that the density of the slag can be estimated. The sample was usually melted at a temperature $50^{\circ} \mathrm{C}$ higher than the liquidus temperature which can be predicted by FactSage 6.2. ${ }^{21,22)}$ After melting, the crucible with sample was slow cooled to room temperature for high temperature measurement.

When the viscosity measurements have been completed, the sample was dropped into water so that phase assemblages at temperature can be retained. The quenched samples were sectioned, mounted, polished and carbon coated for EPMA measurement. A JXA 8200 Electron Probe Microanalyser with Wavelength Dispersive Detectors was used for microstructure and composition analyses. The analysis was conducted at an accelerating voltage of $15 \mathrm{kV}$ and a probe current of $15 \mathrm{nA}$. The standards used for analysis were supplied by Charles M Taylor Co., Stanford, California, USA: $\mathrm{CaSiO}_{3}$ for $\mathrm{Si}$ and $\mathrm{Ca}, \mathrm{Al}_{2} \mathrm{O}_{3}$ for $\mathrm{Al}, \mathrm{Fe}_{2} \mathrm{O}_{3}$ for $\mathrm{Fe}, \mathrm{TiO}_{2}$ for $\mathrm{Ti}, \mathrm{MgO}$ for $\mathrm{Mg}, \mathrm{Mn}_{3} \mathrm{Al}_{2} \mathrm{Si}_{3} \mathrm{O}_{12}$ for $\mathrm{Mn}, \mathrm{CuFeS}_{2}$ for $\mathrm{S}$ and $\mathrm{CaMoO}_{4}$ for Mo. The ZAF correction procedure supplied with the electron probe was applied. The average accuracy of the EPMA measurements was within $1 \mathrm{wt} \%$.

The uncertainties associated with the viscosity measurements have been discussed in a previous study. ${ }^{19)}$ It was found that 
1) The total weight of the spindle used for the rheometer needs to be controlled below $210 \mathrm{~g}$;

2) The gap between spindle and crucible wall needs to be greater than $3 \mathrm{~mm}$;

3) The distance between the spindle tip and bottom of the crucible needs to be greater than $8 \mathrm{~mm}$;

4) The error associated with the thermal expansion of the Mo spindle is below 3 pct.

All efforts have been made to reduce the possible errors associated with high temperature viscosity measurements.

\section{Results}

Viscosity measurements have been carried out for one industrial blast furnace slag SG1 and three synthetic slags (BF1, BF2 and BF3). The compositions of BF1, BF2 and $\mathrm{BF} 3$ were prepared to have constant $17 \mathrm{wt} \% \mathrm{Al}_{2} \mathrm{O}_{3}$ and basicity $\left(\mathrm{CaO} / \mathrm{SiO}_{2}\right)$ equal to 1.1 with different $\mathrm{MgO}$ concentrations in the slag. Synthetic slag BF3 has a composition close to the industrial slag SG1 so that effects of minor components such as $\mathrm{FeO}, \mathrm{TiO}_{2}$ and sulphur on viscosity can be evaluated. All samples were quenched directly after the viscosity measurements at lowest measuring temperature. Inspection of quenched samples confirms that all viscosity measurements were carried out above the liquidus temperatures so that only liquid phase was present during the viscosity measurements (Fig. 2).

The compositions of industrial and synthetic slags were analysed by EPMA after the viscosity measurements (see Table 2). It can be seen from Table 2 that in addition to the major components $\mathrm{Al}_{2} \mathrm{O}_{3}, \mathrm{CaO}, \mathrm{MgO}$ and $\mathrm{SiO}_{2}, 0.4 \mathrm{wt} \%$ $\mathrm{FeO}, 0.7 \mathrm{wt} \% \mathrm{TiO}_{2}$ and $1.2 \mathrm{wt} \% \mathrm{~S}$ are also present in the

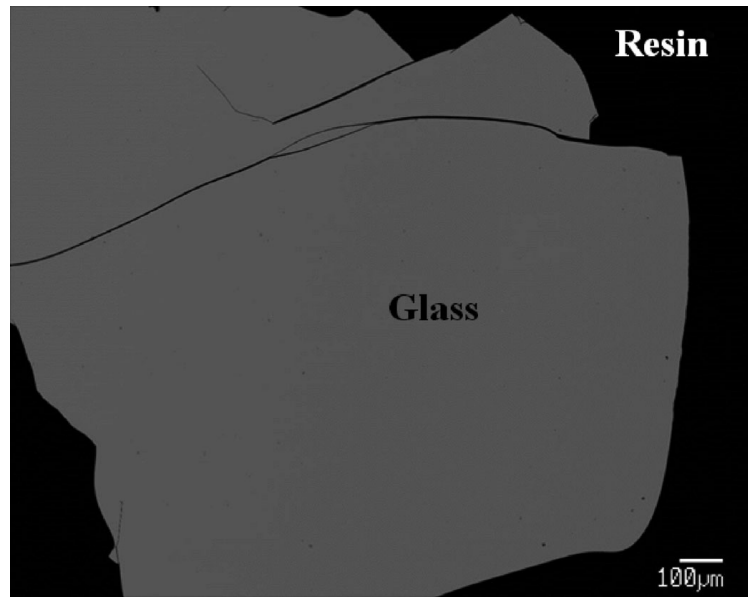

Fig. 2. Backscattered scanning electron micrographs of quenched SG1 samples after viscosity measurement at $1420^{\circ} \mathrm{C}$.

Table 2. The measured compositions by EPMA analysis.

\begin{tabular}{lllllllllllll}
\hline \multirow{2}{*}{ Sample } & $\begin{array}{c}\mathrm{CaO} / \\
\mathrm{SiO}_{2}\end{array}$ & \multicolumn{8}{c}{ Measured compositions (wt\%) } \\
\cline { 3 - 11 } & $\mathrm{SiO}_{2}$ & $\mathrm{CaO}$ & $\mathrm{Al}_{2} \mathrm{O}_{3}$ & $\mathrm{MgO}$ & $\mathrm{FeO}$ & $\mathrm{TiO}_{2}$ & $\mathrm{MnO}$ & $\mathrm{S}$ & $\mathrm{MoO}_{3}$ \\
\hline $\mathrm{SG} 1$ & 1.15 & 34.1 & 39.2 & 16.1 & 8.1 & 0.4 & 0.7 & 0.2 & 1.2 & 0 \\
$\mathrm{BF} 1$ & 1.1 & 38 & 41.6 & 17.2 & 3 & 0 & 0 & 0 & 0 & 0.2 \\
$\mathrm{BF} 2$ & 1.1 & 36.5 & 40.2 & 17.2 & 5.8 & 0 & 0 & 0 & 0 & 0.2 \\
$\mathrm{BF} 3$ & 1.1 & 35 & 38.5 & 17.3 & 8.9 & 0 & 0 & 0 & 0 & 0.3 \\
\hline
\end{tabular}

$\mathrm{BF}$ slag. Less than $0.3 \mathrm{wt} \% \mathrm{MoO}_{3}$ was present in the synthetic slags and no Mo was detected in the industrial slags.

The measured viscosities are listed in Table 3 and plotted in Fig. 3 as a function of temperature. It can be seen that SG1 has the lowest viscosities and BF1 has the highest viscosities in the temperature range investigated.

Table 3. The measured viscosities in the present study.

\begin{tabular}{|c|c|c|}
\hline Sample & Temperature $\left({ }^{\circ} \mathrm{C}\right)$ & Viscosity (Pa.s) \\
\hline \multirow{5}{*}{ SG1 } & 1420 & 0.510 \\
\hline & 1450 & 0.406 \\
\hline & 1500 & 0.288 \\
\hline & 1550 & 0.207 \\
\hline & 1600 & 0.156 \\
\hline \multirow{6}{*}{$\mathrm{BF} 1$} & 1400 & 1.121 \\
\hline & 1450 & 0.702 \\
\hline & 1500 & 0.482 \\
\hline & 1525 & 0.399 \\
\hline & 1550 & 0.352 \\
\hline & 1575 & 0.295 \\
\hline \multirow{7}{*}{$\mathrm{BF} 2$} & 1400 & 0.891 \\
\hline & 1450 & 0.581 \\
\hline & 1475 & 0.478 \\
\hline & 1500 & 0.408 \\
\hline & 1525 & 0.335 \\
\hline & 1550 & 0.290 \\
\hline & 1575 & 0.247 \\
\hline \multirow{7}{*}{$\mathrm{BF} 3$} & 1425 & 0.580 \\
\hline & 1450 & 0.479 \\
\hline & 1475 & 0.395 \\
\hline & 1500 & 0.341 \\
\hline & 1525 & 0.286 \\
\hline & 1550 & 0.250 \\
\hline & 1575 & 0.211 \\
\hline
\end{tabular}

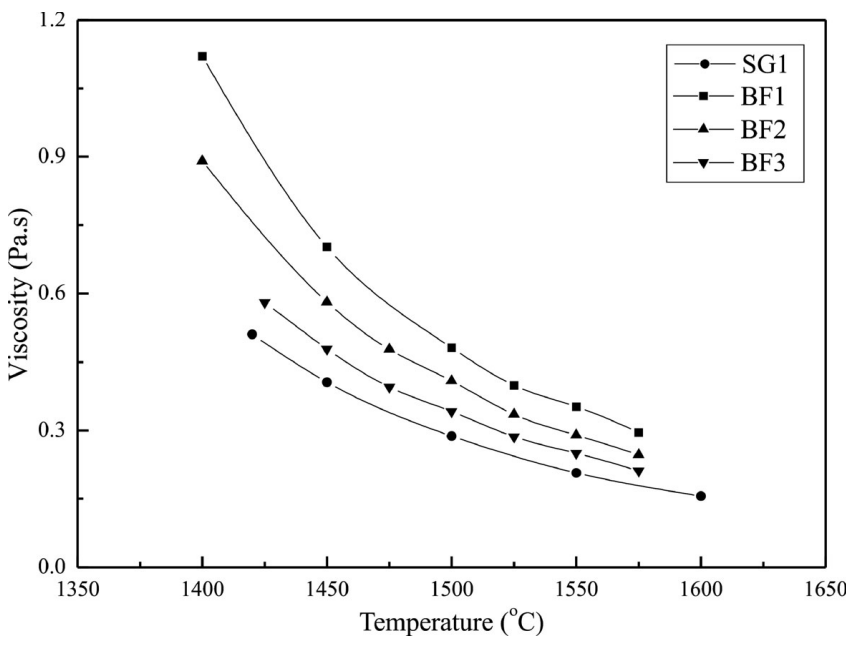

Fig. 3. Viscosities of the measured samples as a function of temperature. 
The temperature dependence of the viscosity for a given slag composition can be described by Arrhenius-type equation: ${ }^{23)}$

$$
\eta=A \exp \left(\frac{E a}{R T}\right)
$$

where $\eta$ is the viscosity in Pa.s, $\mathrm{T}$ is the absolute temperature in $\mathrm{K}, \mathrm{R}$ is the gas constant $\left(8.314 \mathrm{~J} / \mathrm{mol}^{*} \mathrm{~K}\right)$. The temperatureindependent parameters $\mathrm{A}$ and $\mathrm{Ea}$ are the pre-exponential factor and the activation energy $(\mathrm{kJ} / \mathrm{mol})$, respectively. The Arrhenius-type equation can be re-arranged after taking logarithm:

$$
\ln \eta=A+\frac{E a}{R T}
$$

Equation (3) shows that $\ln \eta$ has a linear relationship with $1 / \mathrm{T}$ and the slope of the line is the activation energy Ea. It can be seen from Fig. 4 that all slags measured in the present study follow the Arrhenius behaviour.

Activation energies derived from Fig. 4 are 174, 194, 188 and $174 \mathrm{~kJ} / \mathrm{mol}$ for SG1, BF1, BF2 and BF3, respectively. It seems that presence of the minor components such as $\mathrm{FeO}, \mathrm{TiO}_{2}$ and $\mathrm{S}$ in the slag (SG1) does not affect the activation energy. The activation energy decreases with increasing $\mathrm{MgO}$ concentration in the slag.

\section{Discussions}

\subsection{Viscosities of Industrial BF Slags}

Experimentally determined viscosities of the Baosteel blast furnace slags ${ }^{24)}$ are compared with the present results (Fig. 5). It can be seen that the viscosities of Baosteel and Shougang BF slags are in the range of $0.25-0.4 \mathrm{~Pa} . \mathrm{s}$ at temperatures between 1530 and $1470^{\circ} \mathrm{C}$. This indicates that the blast furnace slags in Baosteel and Shougang have good fluidity at normal operating temperatures if solid phases are not present.

\subsection{Comparison of Viscosities between Industrial Slag and Synthetic Slag}

One of the aims in the present study was to investigate the difference between industrial slag and synthetic slag on vis-

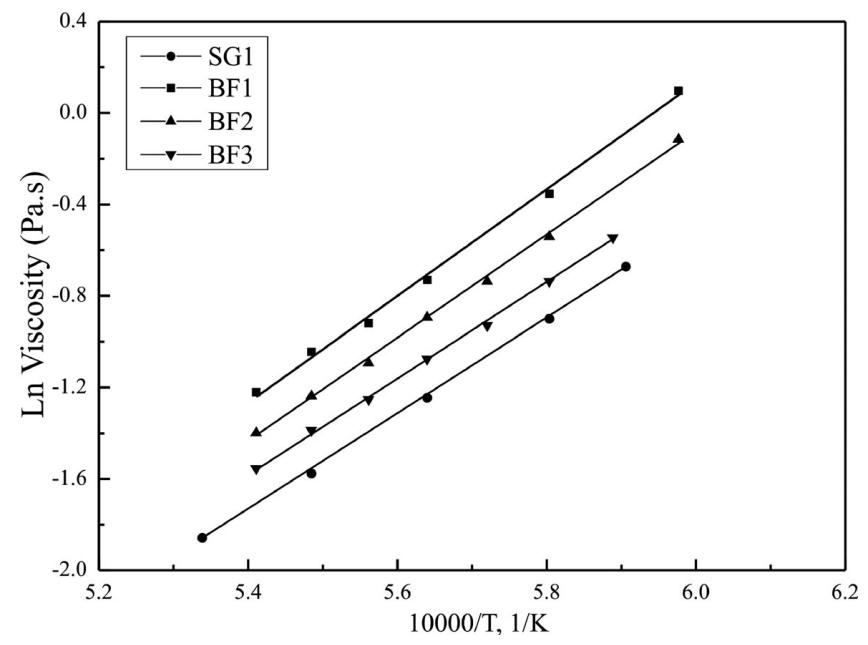

Fig. 4. Linear relationship between $\ln \eta$ and $10000 / \mathrm{T}$. cosity. Most of BF slag viscosity has been investigated for four-component slag $\mathrm{Al}_{2} \mathrm{O}_{3}-\mathrm{CaO}-\mathrm{MgO}-\mathrm{SiO}_{2}$. Comparison of the viscosities between industrial slag and synthetic slag will enable the measurements and predictions of the viscosities of the synthetic slags to be directly used for industrial Bf slags. It is clearly seen from Fig. 3 that the viscosities of the industrial slag SG1 are approximately 20\% lower than its corresponding synthetic slags $\mathrm{BF} 3$ at a given temperature. It is well known that $\mathrm{FeO}$ and $\mathrm{MnO}$ can decrease the viscosity. ${ }^{25-28)} \mathrm{TiO}_{2}$ was also reported to decrease the viscosity based on the experimental study carried out by Shankar et $a l .{ }^{9)}$ and Park et al. ${ }^{29)}$ Effect of sulphur on the viscosity of BF slag is still not clear. Lower viscosities of the industrial BF slag comparing to the synthetic slags are combined results of all minor components. Further study is required to investigate individual effect of the minor components on viscosity of BF slags.

\subsection{Effect of MgO on Viscosity of BF Slag}

The viscosities of the synthetic slags BF1, BF2 and BF3 were measured to evaluate the effect of the substitution of $\left(\mathrm{CaO}+\mathrm{SiO}_{2}\right)$ by $\mathrm{MgO}$ in the slag while controlled a constant $\mathrm{Al}_{2} \mathrm{O}_{3}$ concentration and $\mathrm{CaO} / \mathrm{SiO}_{2}$ ratio of 1.1 (Table 1). Figure 6 shows that the viscosity gradually decreases with the increase of $\mathrm{MgO}$ and the effect is more significant at low temperature. $\mathrm{CaO} / \mathrm{SiO}_{2}$ ratio in $\mathrm{BF}$ slag is usually fixed to maintain the sulphur capacity of the slag. Besides $\mathrm{SiO}_{2}$, $\mathrm{Al}_{2} \mathrm{O}_{3}$ may also increase viscosity with association of basic oxides, such as $\mathrm{CaO},{ }^{30-32)}$ which is abundant in the BF slags. The mechanism can be explained as the "charge compensation effect", ${ }^{33)}$ in which $\mathrm{Al}^{3+}$ can be charge compensated by $\mathrm{Ca}^{2+}$ and $\mathrm{Mg}^{2+}$ to continue the silicate network. The enriched $\mathrm{CaO}$ in $\mathrm{BF}$ slag can fully charge compensate the $\mathrm{Al}_{2} \mathrm{O}_{3}$, so that increased $\mathrm{Al}_{2} \mathrm{O}_{3}$ concentration in the $\mathrm{BF}$ slag results in higher viscosity. One of the strategies to decrease viscosity of the $\mathrm{BF}$ slag is to add more $\mathrm{MgO}$ in the feed while the $\mathrm{CaO} / \mathrm{SiO}_{2}$ ratio keeps the same. Accordingly, $(\mathrm{CaO}+\mathrm{MgO}) / \mathrm{SiO}_{2}$ ratio in $\mathrm{BF}$ slag and slag mass will be increased.

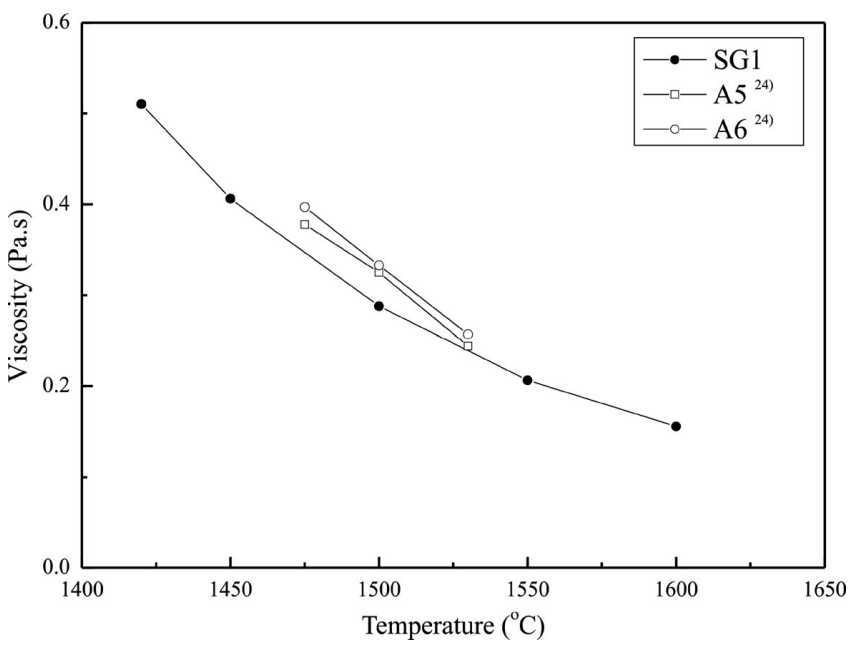

Fig. 5. The comparison of viscosities of SG1 from Shougang slag with Baosteel industrial slags. ${ }^{24)}\left(\mathrm{A} 5: \mathrm{SiO}_{2}\right.$ 35.6, $\mathrm{CaO} 40.9$, $\mathrm{Al}_{2} \mathrm{O}_{3}$ 15.5, $\mathrm{MgO} 8.0 \mathrm{wt} \% ; \mathrm{A}^{2}: \mathrm{SiO}_{2} 34.9, \mathrm{CaO} 40.1, \mathrm{Al}_{2} \mathrm{O}_{3}$ 17.0, $\mathrm{MgO} 8.0 \mathrm{wt} \%$ ). 


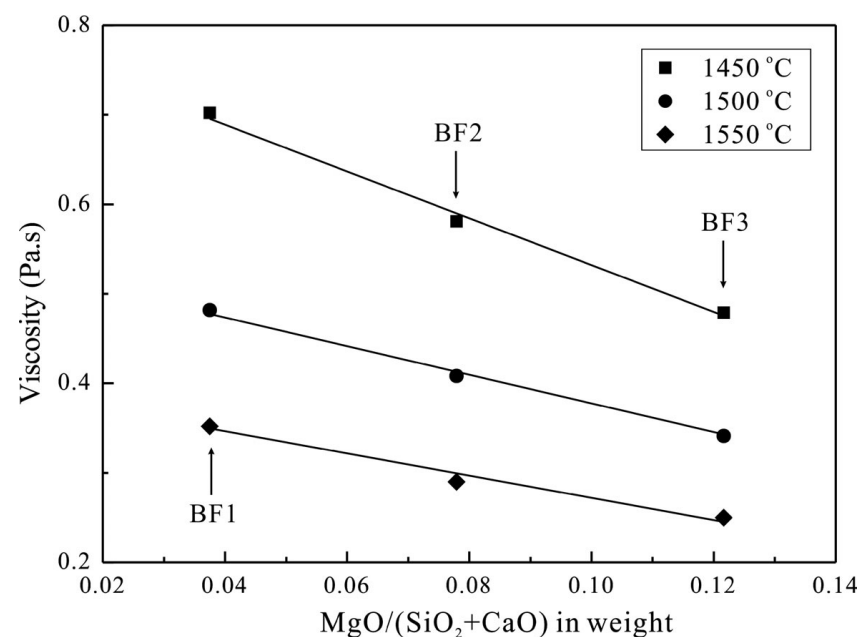

Fig. 6. The comparison of present results at temperature 1450, 1500 and $1500^{\circ} \mathrm{C}$.

\subsection{Viscosities between Synthetic Slags}

The viscosities are compared for the synthetic slags between the present study and previous data (Fig. 7). The viscosities measured by Hofmann ${ }^{6}$ and Machin $^{4}$ (Table 4) have the compositions close to the present study. The liquidus temperatures of these samples were predicted by Factsage 6.2. ${ }^{21,22)}$ It can be seen from Fig. 7 that some of the measurements were carried out below the predicted liquidus. However, presence of the solid in the slag during the viscosity measurements was not mentioned in these studies. ${ }^{4,6)}$ The slag compositions reported by Hofmann ${ }^{6}$ and Machin ${ }^{4)}$ were designed to keep the constant $\mathrm{SiO}_{2}$ and $\mathrm{Al}_{2} \mathrm{O}_{3}$ concentrations, and also constant $(\mathrm{CaO}+\mathrm{MgO}) / \mathrm{SiO}_{2}$ ratio. It can be seen from $\mathrm{H} 1$ to $\mathrm{H} 3$, and M1 to M2 that, substitution of $\mathrm{CaO}$ by $\mathrm{MgO}$ can decrease the slag viscosity. The compositions of $\left.\mathrm{H} 3,{ }^{6}\right) \mathrm{M}^{4}$ ) and $\mathrm{BF} 3$ are close. But it can be seen from Fig. 7 that the viscosities of $\mathrm{BF} 3$ and $\mathrm{M}^{4}$ ) are much higher than that of $\mathrm{H}^{6}{ }^{6}$ at a given temperature. This demonstrates that not all viscosity data reported previously are accurate. It is important to use only accurate viscosity data to assist in operation and viscosity model development.

\subsection{Sensitivities of Viscosity to Major Components}

$\mathrm{BF}$ slag can be represented by four-component system $\mathrm{Al}_{2} \mathrm{O}_{3}-\mathrm{CaO}-\mathrm{MgO}-\mathrm{SiO}_{2}$. It would be easy to control slag composition if the viscosity can be predicted from slag chemistry. However, a complete mathematical viscosity model requires good theoretical base and a large number of accurate measurements. As a first approximation, the following empirical correlation is obtained from the present viscosity data and data reported by Machin ${ }^{4)}$ at $1500^{\circ} \mathrm{C}$ :

$$
\begin{aligned}
\mathrm{V}= & 0.005+0.0262\left[\mathrm{SiO}_{2}\right]+0.0184\left[\mathrm{Al}_{2} \mathrm{O}_{3}\right] \\
& -0.0172[\mathrm{CaO}]-0.0244[\mathrm{MgO}]
\end{aligned}
$$

Where $\left[\mathrm{SiO}_{2}\right],[\mathrm{CaO}],\left[\mathrm{Al}_{2} \mathrm{O}_{3}\right]$ and $[\mathrm{MgO}]$ are in weight percent and viscosity is in Pa.s. The composition range for the regression includes $\mathrm{CaO} 25-50, \mathrm{SiO}_{2} 30-45, \mathrm{MgO} 0-15$ and $\mathrm{Al}_{2} \mathrm{O}_{3} 5-25 \mathrm{wt} \%$. The overall error range of the coefficients in Eq. (4) is estimated to be less than $10 \%$. The parameters in front of each component indicate the positive and negative effects and their significances to the viscosity. It can be seen from Eq. (4) that the increase of the viscosity

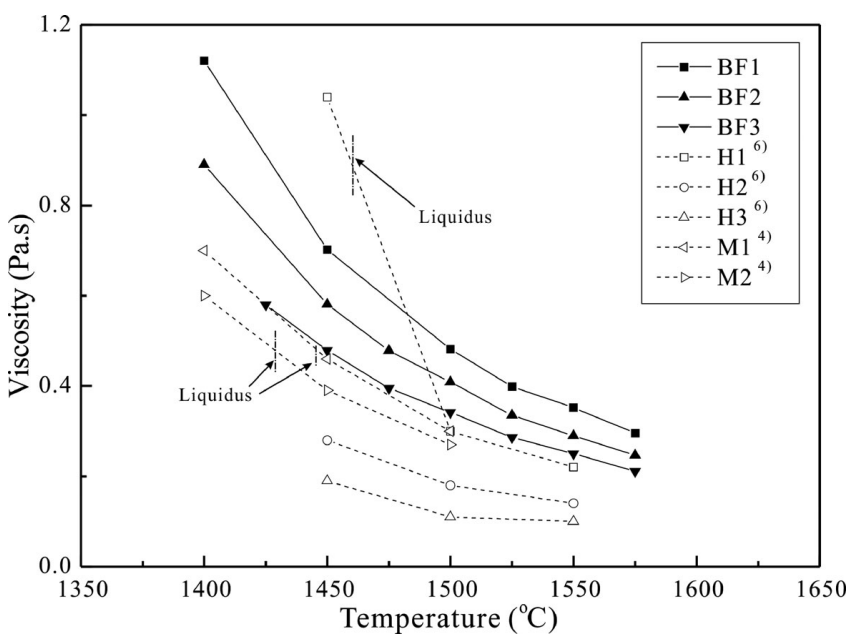

Fig. 7. Comparison of present results with data from Hofmann ${ }^{6}$ and Machin. ${ }^{4)}$

Table 4. The viscosity data reported by Hofmann ${ }^{6)}$ and Machin. ${ }^{4}$

\begin{tabular}{crrrrrc}
\hline \multirow{2}{*}{ Sample } & \multicolumn{4}{c}{ Composition (wt\%) } & Basicity & \begin{tabular}{c} 
Liquidus temperature \\
\cline { 2 - 5 }
\end{tabular} \\
\cline { 2 - 5 } $\mathrm{SiO}_{2}$ & $\mathrm{CaO}$ & $\mathrm{Al}_{2} \mathrm{O}_{3}$ & $\mathrm{MgO}$ & & 1465 \\
\hline $\mathrm{H}^{6)}$ & 34.3 & 45.8 & 16.6 & 3.3 & 1.34 & 1447 \\
$\mathrm{H}^{6)}$ & 34.8 & 41.7 & 16.9 & 6.7 & 1.20 & 1423 \\
$\mathrm{H}^{6)}$ & 35.2 & 37.6 & 17.1 & 10.1 & 1.07 & 1443 \\
$\mathrm{M}^{4)}$ & 35.0 & 45.0 & 15.0 & 5.0 & 1.29 & 1424 \\
$\mathrm{M}^{4}{ }^{4)}$ & 35.0 & 40.0 & 15.0 & 10.0 & 1.14 & \\
\hline
\end{tabular}

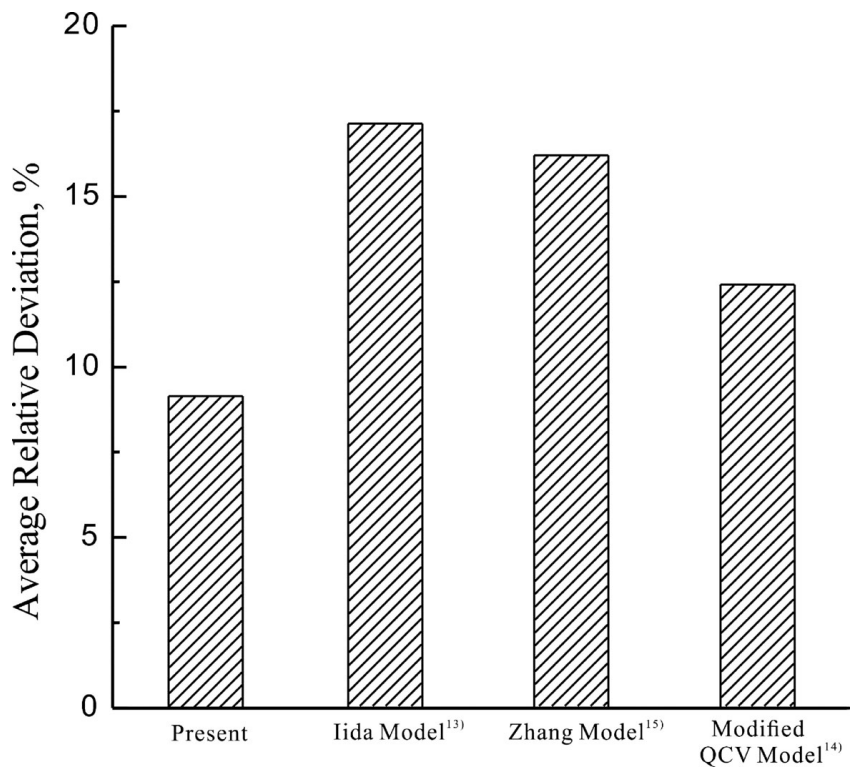

Fig. 8. Comparison of the average relative deviation for different models.

by $\mathrm{Al}_{2} \mathrm{O}_{3}$ is approximately $70 \%$ of that caused by the same weight $\mathrm{SiO}_{2}$. In real industrial practice, same weight of $\mathrm{MgO}$ decreases the viscosity more than that of $\mathrm{CaO}$, which is consistent with the conclusions made by Biswas ${ }^{2)}$ and Machin. ${ }^{3-5)}$ With a lower molecular weight of $\mathrm{MgO}$, replacing the same weight of $\mathrm{CaO}$ by $\mathrm{MgO}$ means the mole ratio of $(\mathrm{CaO}+\mathrm{MgO}) / \mathrm{SiO}_{2}$ is increased and the silicate network is further modified. 
Selected BF viscosity models ${ }^{13-15)}$ are reproduced and calculated using the same compositions. The average relative deviations of the present model and other models are calculated and plotted in Fig. 8. It can be seen that the empirical correlation obtained from our measurements and Machin's data ${ }^{4)}$ can be used as a fast prediction of viscosity for BF slag within the given range.

\section{Conclusion}

Viscosity measurements have been carried out for granulated iron blast furnace slags from Shougang and corresponding synthetic slags. The microstructures and phase compositions of the quenched slag samples were determined by EPMA and the bulk composition of industrial slag sample was measured by XRF after the viscosity measurement.

It was found that the viscosities of the industrial BF slags are in the range of 0.3 to $0.5 \mathrm{~Pa} . \mathrm{s}$ at $1500^{\circ} \mathrm{C}$. The viscosities of the synthetic slag are higher than that of the corresponding industrial slag which contains minor components. The viscosities measured in the present study are compared with previous data for industrial and synthetic slags. It was found that the viscosity decreases with increasing $\mathrm{MgO}$ at constant $\mathrm{Al}_{2} \mathrm{O}_{3}$ and basicity. The differences of the viscosities between industrial slags and synthetic slags provide useful indications to apply the laboratory-based results of the synthetic slags to the operation of the iron blast furnace.

The effects of $\mathrm{CaO}, \mathrm{SiO}_{2}, \mathrm{MgO}$ and $\mathrm{Al}_{2} \mathrm{O}_{3}$ in the $\mathrm{BF}$ slag on the viscosity have been evaluated from the present and previous viscosity measurements.

\section{Acknowledgement}

The authors would like to thank Ms. Jie Yu for the lab assistance in the viscosity measurements.

The authors would like to thank The University of Queensland, Shougang and Hamersley for their financial support.

\section{REFERENCES}

1) A. Muan and E. F. Osborn: Phase Equilibria among Oxides in Steelmaking, Addison-Wesley Publishing Company, Boston, (1965).
2) A. K. Biswas: Principles of Blast Furnace Ironmaking: Theory and Practice, Cootha publishing house, Brisbane, (1981).

3) J. S. Machin and D. L. Hanna: J. Am. Ceram. Soc., 28 (1945), 310.

4) J. S. Machin, T. B. Yee and D. L. Hanna: J. Am. Ceram. Soc., 35 (1952), 322.

5) J. S. Machin and T. B. Yee: J. Am. Ceram. Soc., 37 (1954), 177.

6) E. E. Hofmann: Berg- und hüttenmännische monatshefte, 106 (1959), 397.

7) L. Forsbacka, L. Holappa, T. Iida, Y. Kita and Y. Toda: Scand. J. Metall., 32 (2003), 273.

8) J. H. Park, D. J. Min and H. S. Song: Metall. Mater. Trans. B, 35 (2004), 269.

9) A. Shankar, M. Görnerup, A. K. Lahiri and S. Seetharaman: Metall. Mater. Trans. B, 38 (2007), 911.

10) J. H. Park, H. Kim and D. J. Min: Metall. Mater. Trans. B, 39 (2008), 150 .

11) E. Osborn, R. C. DeVries, K. H. Gee and H. M. Kraner: Trans. AIME, 200 (1954), 33.

12) A. Kondratiev and E. Jak: Metall. Mater. Trans. B, 32 (2001), 1015.

13) T. Iida, H. Sakai, Y. Kita and K. Shigeno: ISIJ Int., 40 (2000), 110.

14) M. Suzuki and E. Jak: Metall. Mater. Trans. B, 44 (2013), 1.

15) G. Zhang, K. Chou and K. Mills: Metall. Mater. Trans. B, 44 (2013),

16) K. Mills and S. Sridhar: Ironmaking Steelmaking, 26 (1999), 262.

17) X. Tang, M. Guo, X. Wang, Z. Zhang and M. Zhang: Beijing Keji Daxue Xuebao, 32 (2010), 1542.

18) X. Hu, Z. Ren, G. Zhang, L. Wang and K. Chou: Int. J. Miner. Metall. Mater., 19 (2012), 1088.

19) M. Chen, S. Raghunath and B. Zhao: Metall. Mater. Trans. B, 44 (2013), 506.

20) M. Chen, S. Raghunath and B. Zhao: Metall. Mater. Trans. B, 44 (2013), 820 .

21) C. W. Bale, P. Chartrand, S. A. Degterov, G. Eriksson, K. Hack, R. B. Mahfoud, J. Melancon, A. D. Pelton and S. Petersen: Calphad, 26 (2002), 189

22) C. W. Bale, E. Belisle, P. Chartrand, S. A. Decterov, G. Eriksson, K. Hack, I. H. Jung, Y. B. Kang, J. Melancon, A. D. Pelton, C. Robelin and S. Petersen: Calphad, 33 (2009), 295.

23) P. W. Atkins: Physical Chemistry, 4th ed., Oxford Univ. Press, Oxford, (1990).

24) Q. Yu, L. L. Zhang and C. C. Lin: Baosteel Tech., 3 (2002), 37.

25) M. Kucharski, N. Stubina and J. Toguri: Can. Metall. Q., 28 (1989), 7 .

26) Y. Shiraishi, K. Ikeda, A. Tamura and T. Sairo: Trans. JIM, 19 (1978), 264

27) G. Urbain, Y. Bottinga and P. Richet: Geochim. Cosmochim. Acta, 46 (1982), 1061.

28) F. Z. Ji, D. Sichen and S. Seetharaman: Metall. Mater. Trans. B, 28 (1997), 827.

29) H. Park, J. Y. Park, G. H. Kim and I. Sohn: Steel Res. Int., 83 (2012), 150.

30) P. Kozakevitch: Rev. Met., 57 (1960), 149.

31) G. Urbain, Y. Bottinga and P. Richat: Geochim. Cosmoschim. Acta, 46 (1982), 1061

32) M. J. Toplis and D. B. Dingwell: Geochim. Cosmochim. Acta, 68 (2004), 5169.

33) B. O. Mysen: Eur. J. Miner., 15 (2003), 781. 